\title{
Consumption of large bathyal food fall, a six month study in the NE Atlantic
}

\author{
Kirsty M. Kemp ${ }^{1, *}$, Alan J. Jamieson ${ }^{1}$, Philip M. Bagley ${ }^{1}$, Helen McGrath ${ }^{1}$, \\ David M. Bailey ${ }^{1}$, Martin A. Collins ${ }^{2}$, Imants G. Priede ${ }^{1}$ \\ ${ }^{1}$ Oceanlab, University of Aberdeen, Main Street, Newburgh, Ellon, Aberdeenshire AB41 6AA, UK \\ ${ }^{2}$ British Antarctic Survey, Natural Environment Research Council, High Cross, Madingley Road, Cambridge CB3 0ET, UK
}

\begin{abstract}
We deployed 2 porpoise (Phocoena phocoena) carcasses at bathyal depth (2555 to $2710 \mathrm{~m}$ ) in the Porcupine Seabight, NE Atlantic for periods of 1 wk and 6 mo respectively. Consumption rates of 0.085 and $0.078 \mathrm{~kg} \mathrm{~h}^{-1}$ were similar to those observed at abyssal depths in the Atlantic, and 1 order of magnitude slower than at bathyal depth in the Pacific. A distinct succession of scavenging species was observed at both carcasses: the abyssal grenadier Coryphaenoides armatus and the cusk eel Spectrunculus grandis numerically dominated the initial phase of carcass consumption and, once the bulk of the soft tissue had been removed (by Day 15), were succeeded by the squat lobster Munidopsis crassa. The blue hake Antimora rostrata and amphipod numbers were unexpectedly low, and consumption was attributed largely to direct feeding by $C$. armatus. The interaction of a crustacean prey species (M. crassa) and cephalopod predator (Benthoctopus sp.) was observed for the first time, revealing that large food falls also attract secondary predators that do not utilise the food fall directly. The staying time of a single parasitised $C$. armatus $(18 \mathrm{~h})$ greatly exceeded previous estimates $(\leq 8 \mathrm{~h})$. This study describes the first large food fall to be monitored at high frequency over a 6 mo period, and the first observations of a large food fall at bathyal depth in the NE Atlantic. It enables direct comparison with similarly sized food falls at abyssal depth, much larger megacarrion falls, and similar studies differing in geographic location, in particular those carried out under Pacific whale migration corridors.
\end{abstract}

KEY WORDS: Food fall · Time-series · Scavenger · Deep-sea $\cdot$ Benthoctopus sp. $\cdot$ Coryphaenoides armatus $\cdot$ Munidopsis crassa $\cdot$ Deep ocean benthic observatory

\section{INTRODUCTION}

Secondary production in the deep sea is largely driven by the sinking of organic matter originating in the euphotic zone (Rowe 1981, Fowler \& Knauer 1986). The dependency of the benthic ecosystem on this downward flux of carbon makes it a limiting factor affecting reproductive potential (Tyler et al. 1982, Witte 1996), growth rates (Gage \& Tyler 1985, Gage 1990) and activity (Priede \& Bagley 1994) of benthic fauna at slope and abyssal depths. Nekton carcasses, from fishes and birds (mesocarrion $\sim 1 \mathrm{~kg}$ ) to seals and dolphins (macrocarrion $\sim 100 \mathrm{~kg}$ ) and the largest cetaceans (megacarrion $>100000 \mathrm{~kg}$ ) comprise a frac- tion of total organic fallout (Britton \& Morton 1994). These constitute point source organic inputs to the benthos and are of particular importance as a food source to large motile scavenging fauna (Stockton \& DeLaca 1982 and references therein).

Natural food falls have been simulated in the deep ocean worldwide using baited camera systems (Priede \& Bagley 2000) and uniformly elicit a very rapid response from scavenging fauna. Small food parcels (fish carcasses) are located and consumed within hours by a highly mobile scavenging assemblage. Larger food falls (small cetacean or shark carcasses) deployed to abyssal depths are consumed over a period of weeks, with a succession of scavenging species becoming ap- 
parent over longer observation periods (Jones et al. 1998, Witte 1999, Janßen et al. 2000). The less transient nature of larger falls extends their role beyond that of a simple food source. The largest cetacean carcasses, lasting years on the seafloor, support the development of anaerobic conditions and the establishment of chemosynthetic communities (Smith et al. 1989, Bennet et al. 1994, Smith \& Baco 2003). These carcasses become zones of prolonged interaction between scavenging and non-scavenging species, whereby competition and facilitation processes, predation and succession may be observed.

In situ observations complement conventional methods of sampling species composition, diversity and distribution, but also enable direct observations of feeding strategies, interactions and social behaviour of deep benthic and bentho-pelagic fauna. However studies of large food falls remain relatively rare in the scientific literature. To date, high frequency observations of experimental food falls using baited camera systems have been limited in duration to 1 to $2 \mathrm{wk}$. Longer term studies have used repeat visits by remotely operated vehicles and manned submersibles and have only been undertaken in the Pacific (Smith \& Baco 2003).

The present study describes the first large food fall to be monitored at high frequency over a 6 mo period, and the first observations of a large food fall at bathyal depth in the NE Atlantic. It aims at describing the longterm response of the local scavenging community in this region, and enabling comparison of the community response at bathyal and abyssal depths in the North Atlantic, and between macrocarrion and megacarrion food falls. The study further enables the first comparisons to be drawn between community response to food falls on the Pacific and Atlantic slopes.

\section{MATERIALS AND METHODS}

During RRS 'Discovery' cruise 255 (August 2001), 2 deployments were made of the Deep Ocean Benthic Observatory (DOBO) in the Porcupine Seabight (NE Atlantic; see Rice et al. 1991 for details of the study region). The DOBO is an autonomous lander system consisting of a titanium frame upon which is mounted a $35 \mathrm{~mm}$ camera (M8S, Ocean Instrumentation), twin acoustic releases (AR 661 B2S-DDL and RT 661 B2SDDL, Oceano), an upward directed $300 \mathrm{kHz}$ acoustic Doppler current profiler (ADCP) (WHS300-I-SP4, RD Instruments) and an acoustic current meter (ACM; 2D acm97, FSI) (see Jamieson \& Bagley 2005 for full details).

Both deployments were baited with a porpoise (Phocoena phocoena) carcass obtained from The Scot- tish Agricultural College Wildlife Unit, Inverness (both animals had died following attack by bottlenose dolphins).

The camera was oriented facing downwards at an angle of $18^{\circ}$ off vertical, and photographed an area of $1.7 \mathrm{~m}^{2}$ of seafloor from a height of $2 \mathrm{~m}$. It was loaded with $50 \mathrm{~m}$ of Kodak E200 Ektachrome colour reversal film (1400 full frame images). Illumination was provided by two $200 \mathrm{~J}$ strobe flash bulbs. A stretcher comprising a mesh net $(600 \times 2000 \mathrm{~mm}$, mesh size $50 \mathrm{~mm}$ ) held between 2 titanium poles was attached at the base of the lander to carry the bait and keep it in contact with the seafloor upon landing.

The ADCP was mounted at the top of the lander (2.4 $\mathrm{m}$ above ground) and recorded current velocity and direction in ten $3 \mathrm{~m}$ depth bins in the water column above the lander. The ACM was mounted $0.92 \mathrm{~m}$ above the seafloor and recorded current velocity and direction over the carcass. Two $60 \mathrm{~kg}$ steel ballast bars linked to twin acoustic releases (AR 661 B2S-DDL and RT 661 B2S-DDL) and 16 syntactic floats (TS26000, CRP Group) were used to sink and retrieve the DOBO (Jamieson \& Bagley 2005). A VHF radio beacon (RF-700A1, Novatech) and strobe (ST400-A, Novatech) were activated upon surfacing, and a flag aided visual location during recovery. Film, instrument data and carcass remains on the lander frame were then retrieved.

The first deployment (D1) (carcass length $1.12 \mathrm{~m}$, weight $25.9 \mathrm{~kg}$ ) was on 20 August 2001 for $7 \mathrm{~d}$ at a depth of $2555 \mathrm{~m}$ at $50^{\circ} 01^{\prime} 01^{\prime \prime} \mathrm{N}, 13^{\circ} 17^{\prime} 06^{\prime \prime} \mathrm{W}$. Post mortem procedures had left a ventral abdominal incision, which was loosely closed with wire stitches prior to deployment. Images were taken at $7 \mathrm{~min}$ intervals and current measurements at $1 \mathrm{~h}$ intervals.

The second deployment (D2) (carcass length $1.15 \mathrm{~m}$, weight ca. $28 \mathrm{~kg}$ ) was on 29 August 2001 at a depth of $2710 \mathrm{~m}$ at $49^{\circ} 59^{\prime} 00^{\prime \prime} \mathrm{N}, 13^{\circ} 32^{\prime} 59^{\prime \prime} \mathrm{W}$. It was recovered 6 mo later on 16 March 2002 during RRS 'Discovery' cruise 260. This carcass was partially decomposed and had 2 gashes along its dorsal surface prior to deployment. Images were taken at $3 \mathrm{~h}$ intervals and current measurements at $1 \mathrm{~h}$ intervals.

Fauna present at the carcasses were identified to the lowest possible taxonomic level. Samples obtained from trawls were used to validate visual identifications from the images. Individuals of each species present were counted in every frame. Only fishes that were fully in view, near the seabed and orientated horizontally were measured (total length), and all measurements were used to determine species mean lengths for each deployment. Regressions of the mean total length per image were generated to assess change in size over the deployment period. 


\section{RESULTS}

\section{Current regime}

There was a distinct semi-diurnal (12.4 h) oscillation in bottom current flow at both locations. Flow velocity $4 \mathrm{~m}$ above bottom ranged from 2 to $148 \mathrm{~mm} \mathrm{~s}^{-1}$ at D1 (mean $49 \mathrm{~mm} \mathrm{~s}^{-1}$ ) and 2 to $134 \mathrm{~mm} \mathrm{~s}^{-1}$ (mean $39 \mathrm{~mm} \mathrm{~s}^{-1}$ ) at D2. Water temperature remained constant at $2.8^{\circ} \mathrm{C}$ (D1) and $2.0^{\circ} \mathrm{C}$ (D2) throughout the deployments.

\section{Species}

Vertebrate fauna. The fauna apparent at both food falls are given in Table 1; 2 fish species were abundant and persistent at both carcasses, the abyssal grenadier
Coryphaenoides (Nematonurus) armatus (macrourid) and the cusk eel Spectrunculus grandis (ophidiid). We also identified 1 shark, (the Portuguese dogfish Centroscymnus coelolepis), 1 chimaera (the smalleyed rabbitfish Hydrolagus affinis) and 4 other teleosts (the blue hake Antimora rostrata, the arrowtooth eel Histiobranchus bathybius, the cutthroat eel Synaphobranchus kaupi, and the pout eel Lycenchelys albus [zoarcid]) at the baits. Very small grenadiers (116 and $113 \mathrm{~mm}$ ), thought to be juveniles were photographed in 2 instances, on Days 13 and 160. A tiny $(<30 \mathrm{~mm}$ total length) fish thought to be a species of Monognathus was photographed at D2.

Invertebrate fauna. The squat lobster Munidopsis crassa was the most abundant invertebrate during D2. Three species of amphipods were recorded, but confirmatory identifications from trawl specimens were

Table 1. Fauna observed at porpoise (Phocoena phocoena) carcasses during deployments D1 and D2 in Porcupine Seabight, NE Atlantic. Max.no.: maximum ind. at one time; total no.: total over deployment; ${ }^{*}$ : unconfirmed identification

\begin{tabular}{|c|c|c|c|c|c|c|}
\hline \multirow[t]{2}{*}{ PHYLUM/Class/Species } & \multirow[t]{2}{*}{ Family } & \multicolumn{2}{|c|}{ Occurrence (d:h:min) } & \multirow[t]{2}{*}{$\%$ images } & \multirow[t]{2}{*}{ Max. no. } & \multirow[t]{2}{*}{ Total no } \\
\hline & & & & & & \\
\hline \multicolumn{7}{|l|}{ Deployment D1 } \\
\hline \multicolumn{7}{|l|}{ CHORDATA } \\
\hline \multicolumn{7}{|l|}{ Chondrichthyes } \\
\hline Centroscymnus coelolepis* & Squalidae & $02: 11: 25$ & $05: 14: 24$ & 0.07 & 1 & 5 \\
\hline Hydrolagas affiniss & Chimaeridae & 01:07:02 & 01:09:50 & 0.1 & 1 & 2 \\
\hline \multicolumn{7}{|l|}{ Osteichthyes } \\
\hline Synaphobranchus kaupi & Synaphobranchidae & 03:20:24 & $03: 20: 24$ & 0.4 & 1 & 1 \\
\hline Coryphaenoides armatus & Macrouridae & $00: 00: 28$ & $06: 14: 33$ & 53 & 6 & 1192 \\
\hline Antimora rostrata & Moridae & 00:00:14 & $06: 12: 06$ & 6 & 1 & 78 \\
\hline Spectrunculus grandis & Ophidiidae & 00:03:09 & $06: 15: 29$ & 86 & 8 & 3337 \\
\hline \multicolumn{7}{|l|}{ Deployment D2 } \\
\hline \multicolumn{7}{|l|}{ CNIDARIA } \\
\hline \multicolumn{7}{|l|}{ Unknown scyphozoan } \\
\hline \multicolumn{7}{|l|}{ MOLLUSCA } \\
\hline Benthoctopus sp. & Octopodidae & $26: 22: 00$ & $63: 22: 00$ & 4.8 & 1 & 64 \\
\hline \multicolumn{7}{|l|}{ CRUSTACEA } \\
\hline Munidopsis sp. & Galatheidae & 07:19:00 & $167: 00: 00$ & 54 & 84 & 18932 \\
\hline Eurythenes gryllus* & Lysianassoidae & & & & & \\
\hline Tmetonyx & Lysianassoidae & & & & & \\
\hline Abyssorchomene* & Lysianassoidae & & & & & \\
\hline \multicolumn{7}{|l|}{ ECHINODERMATA } \\
\hline Zoroaster longicauda & Zoroasteridae & $13: 16: 00$ & $120: 19: 00$ & 12 & 2 & 174 \\
\hline Ophioura ljungmani & Ophiuridae & 19:07:00 & $85: 22: 00$ & 1 & 1 & 26 \\
\hline Peniagone diaphana & Elpidiidae & & & & & \\
\hline Peniagone azorica & Elpidiidae & & & & & \\
\hline Peniagone sp. nov. & Elpidiidae & & & & & \\
\hline \multicolumn{7}{|l|}{$\begin{array}{l}\text { HEMICHORDATA } \\
\text { Unidentified enteropneust }\end{array}$} \\
\hline \multicolumn{7}{|l|}{ CHORDATA } \\
\hline \multicolumn{7}{|l|}{ Osteichthyes } \\
\hline Histiobranchus bathybius & Synaphobranchidae & $102: 22: 00$ & $102: 22: 00$ & 0.07 & 1 & 1 \\
\hline Coryphaenoides armatus & Macrouridae & 00:01:30 & 102:04:00 & 18 & 19 & 968 \\
\hline Juvenile macrourid $^{*}$ & Macrouridae & $13: 01: 00$ & $160: 16: 00$ & 0.01 & 1 & 2 \\
\hline Antimora rostrata & Moridae & $15: 07: 00$ & $43: 22: 00$ & 0.1 & 1 & 2 \\
\hline Lycenchelus albus* & Zoarcidae & 09:13:00 & $121: 13: 00$ & 3 & 2 & 51 \\
\hline Spectrunculus grandis & Ophidiidae & $00: 13: 30$ & $165: 19: 00$ & 24 & 15 & 1144 \\
\hline Monognathus sp.* & Monognathidae & & & & & \\
\hline
\end{tabular}


not possible. We observed 5 species of echinoderms, comprising 1 ophiuroid Ophioura ljungmani, 1 asteroid Zoroaster longicauda, and 3 holothurians Peniagone diaphana, P. azorica and a novel Peniagone species. A single cephalopod, Benthoctopus sp. was observed at D2. Unidentified scyphozoans were observed, but were infrequent during the first 2 wk of D2. They did not conform to the characteristics of any likely candidates for identification: they had a tentacle count of at least 40, far beyond the maximum of 28 recorded for Atolla (Coronatae) or Solmissus (Narcomedusae), the 2 scyphozoan genera they most closely resembled. Ectoparasites were sometimes visible on Coryphaenoides armatus. A hemichordate enteropneust was observed on 3 occasions at D2.

\section{Arrival sequence}

Deployment 1. The blue hake Antimora rostrata was the first species to arrive at D1, 14 min after touchdown
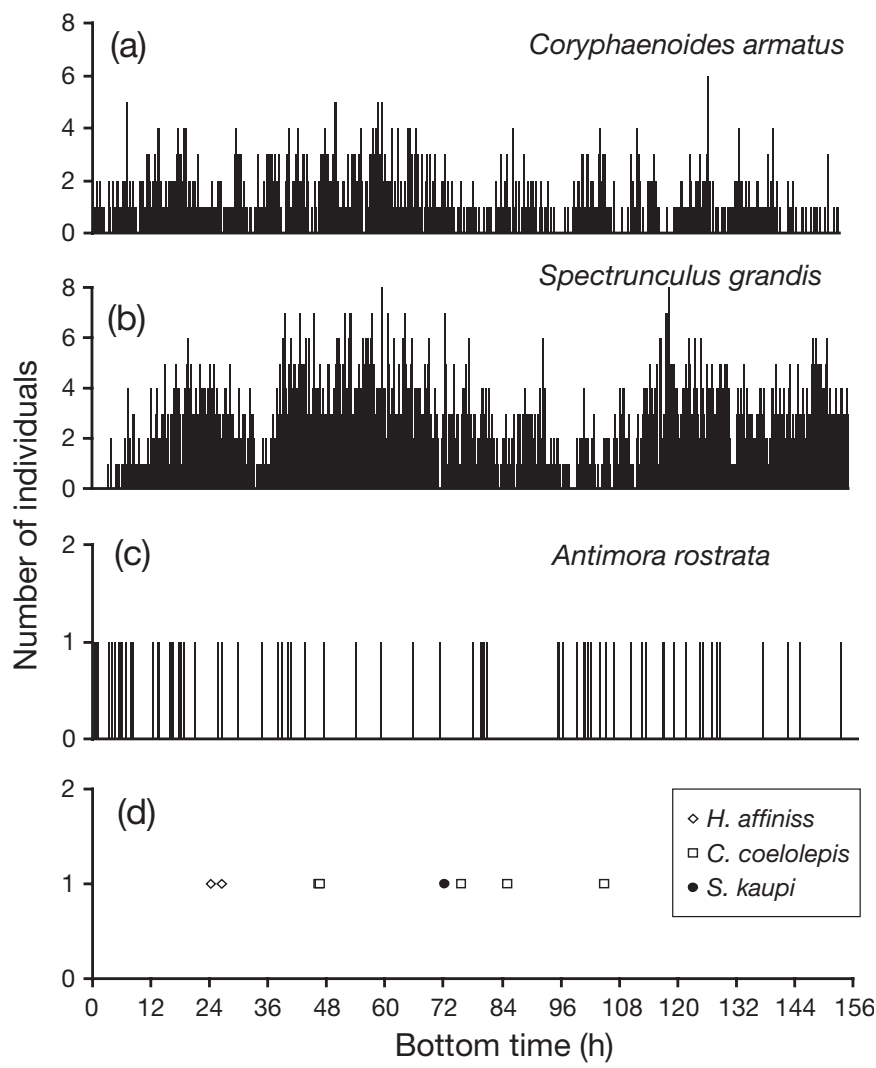

Fig. 1. Species observed at deployment 1 (D1, food fall over $7 \mathrm{~d}$ period, $2555 \mathrm{~m}$, Porcupine Seabight). (a) Coryphaenoides armatus arrived within $28 \mathrm{~min}$ and was present throughout the deployment period; (b) Spectrunculus grandis dominated fish fauna in terms of total number observed; (c) Antimora rostrata arrived first but never exceeded 1 individual frame ${ }^{-1}$; (d) Hydrolagus affiniss, Centroscymnus coelolepis and Synaphobranchus kaupi were observed infrequently
(Fig. 1c). Single individuals of this species subsequently returned at an average interval $( \pm 95 \% \mathrm{CI}, \mathrm{n}=$ 78 ) of $122 \pm 34.5 \mathrm{~min}$. Coryphaenoides armatus arrived within 28 min (Fig. 1a) and Spectrunculus grandis after $3 \mathrm{~h}$ (Fig. 1b). Both species were photographed consistently at the carcass following their initial arrival. The chimaerid Hydrolagus affinis appeared twice at 31 and $33 \mathrm{~h}$ respectively. The cutthroat eel Synaphobranchus kaupi appeared once on Day 72. A single shark, Centroscymnus coelolepis was observed briefly on Days 2, 3 and 4 (Fig. 1d). Ophiuroids, asteroids and amphipods were not present in the D1 images.

Deployment 2. Coryphaenoides armatus was the first fish to arrive at D2, being present in the first image at $1.5 \mathrm{~h}$ after touchdown (Fig. 2a). Spectrunculus grandis was not photographed until $13 \mathrm{~h}$ after touchdown (Fig. 2b). Both species were photographed consistently at the carcass following their initial arrival, their numbers only declining after the bulk of the flesh had been

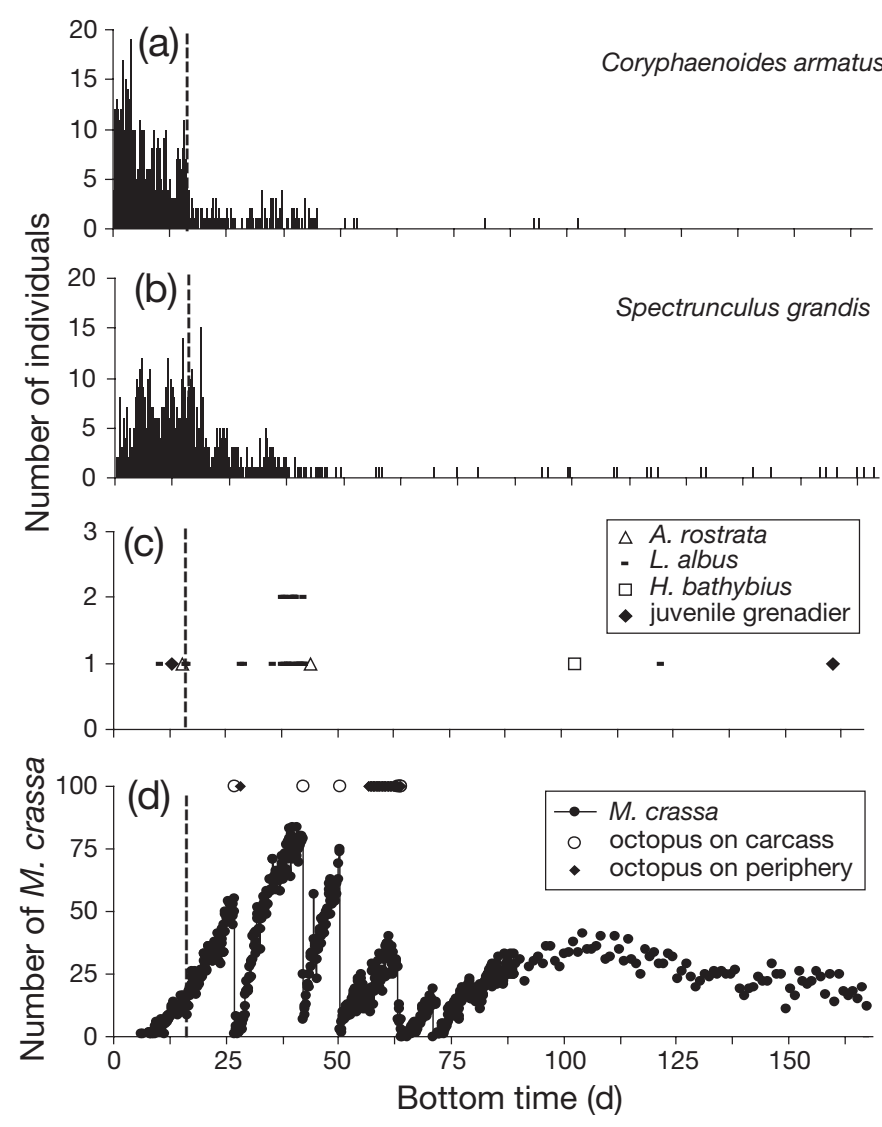

Fig. 2. Species observed at deployment 2 (D2, food fall over 6 mo period $2710 \mathrm{~m}$, Porcupine Seabight). Dashed vertical line represents point at which bulk of soft tissue had been removed (Day 15). (a) Coryphaenoides armatus (arrived first); (b) Spectrunculus grandis dominated fish fauna in terms of total number observed; (c) Antimora rostrata, Lycenchelus albus, Histiobranchus bathybius and juvenile grenadiers were observed infrequently; (d) $M$. crassa numbers oscillated, apparently in response to presence/ absence of a benthoctopus 
removed from the carcass by Day 15. C. armatus numbers declined to $\leq 3$ frame $^{-1}$ on Day 17. S. grandis numbers remained slightly higher and declined to $\leq 5$ frame $^{-1}$ on Day 20. By Day 25, numbers of both species had declined to $\leq 4$ frame $^{-1}$, and by Day 45 only individual fish appeared infrequently. Antimora rostrata were photographed only twice in D2 (Days 15 and 43). The first zoarcid appeared during Day 9 of D2. The next zoarcid appearance was a different individual on Day 15 that remained in the field of view for $\leq 9 \mathrm{~h}$. Zoarcids were observed infrequently until Day 36. Between Days 36 and 41 zoarcids were visible in 32 of the 48 images taken $\left(\max .=2\right.$ frame $\left.^{-1}\right)$, after which only 1 was seen-on Day 121 (Fig. 2c). They were always observed in contact with the seafloor under the mesh of the stretcher, and often partially hidden beneath the stretcher frame or tail of the carcass. No chondricthyes were seen at D2.

The squat lobster Munidopsis crassa arrived at the bait $6 \mathrm{~d}$ after touchdown in D2. They were not present at D1. Following their initial arrival, $M$. crassa numbers increased steadily to 55 individuals on Day 26, and then declined rapidly to 1 individual (Day 26). M. crassa numbers then increased again to the peak number observed over the full deployment period (84 individuals on Day 39), before rapidly declining again to 7 individuals on Day 42. This pattern of increasing numbers followed by a rapid decline was repeated 5 times at intervals of 7 to $15 \mathrm{~d}$. After $85 \mathrm{~d}, \mathrm{M}$. crassa numbers remained comparatively constant $( \pm 95 \%$ CI, $\mathrm{n}=112$, range 11 to 41 ) at $27 \pm 1.1$ individuals frame ${ }^{-1}$ (Fig. $2 d$ ).

A single large octopus (Benthoctopus sp.) was present in 64 images (4.8\% of total), mainly located on the lander frame, 200 to $300 \mathrm{~mm}$ away from the stretcher supporting the carcass (57 images, $4.2 \%$ of total). In 7 images however, the Benthoctopus sp. appeared on the stretcher, in the centre of the field of view; 4 of the 5 rapid reductions in Munidopsis crassa numbers coincided with this observation. The appearance of the Benthoctopus sp. in the centre of the stretcher, and the coincident rapid reduction in $M$. crassa numbers is hereafter referred to as an 'octopus event' (Fig. 3). Individual $M$. crassa were sometimes noted partially obscured in the porpoise skull when an octopus was present, but most vacated the field of view. The 4 th octopus event was preceded by 58 consecutive images $(174 \mathrm{~h})$ in which the octopus was located in the corner of the field of view away from the stretcher. During this time, $M$. crassa numbers were low $( \pm 95 \% \mathrm{CI}$, mean $=$ $25 \pm 2.2$ individuals frame ${ }^{-1}$, range $=6$ to 40 ) but did still increase (40 individuals on Day 61 ). The 5 th and final rapid decline in $M$. crassa numbers occurred on Day 71 and was not preceded by the appearance of an octopus, although the pattern observed is strikingly similar to the previous 4 octopus events. Benthoctopus sp. did not appear again in the $95 \mathrm{~d}$ of further observation. The recovery rates of $M$. crassa (the period between octopus departure and $M$. crassa numbers
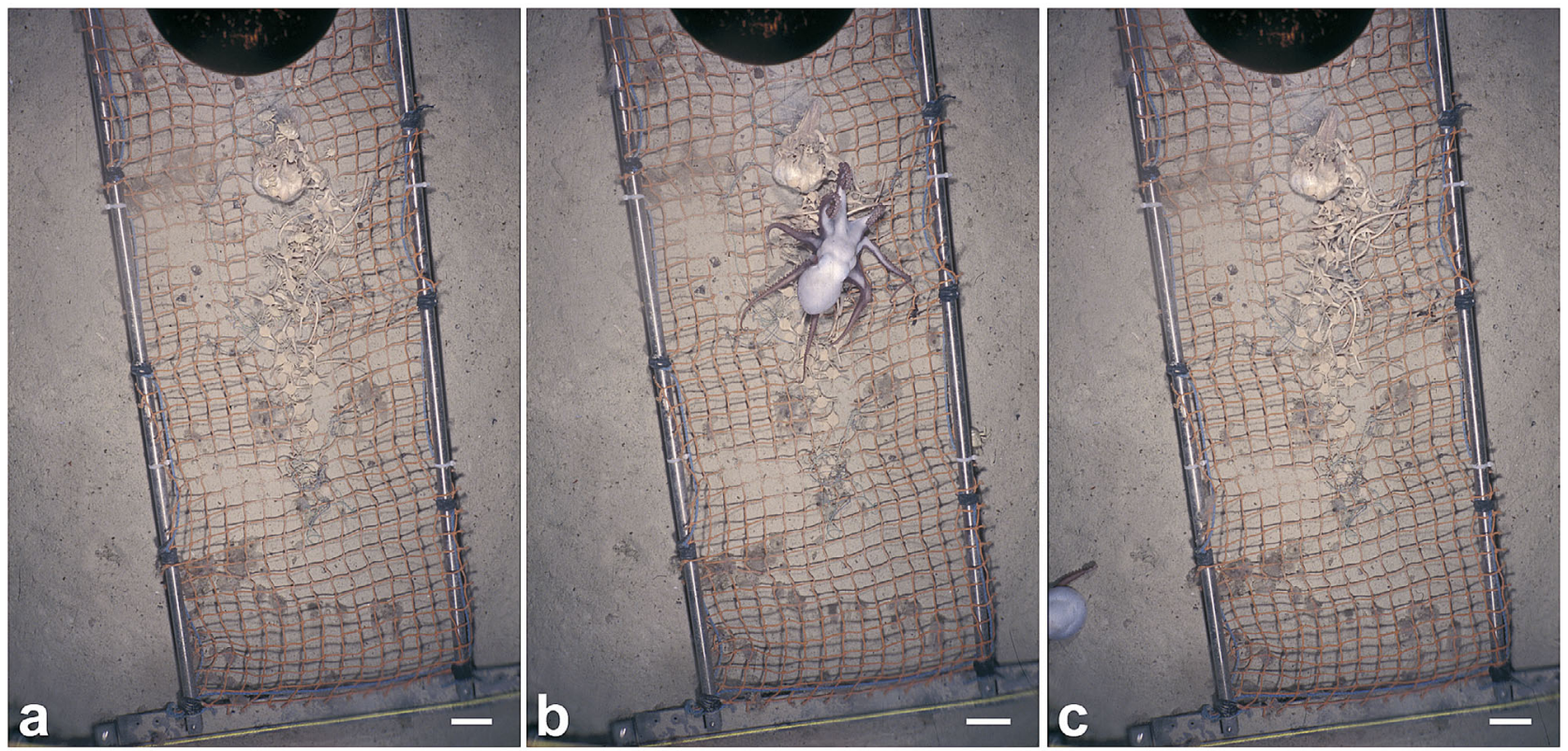

Fig. 3. 'Octopus Event 4' at 2710 m, Porcupine Seabight, during Day 62 of deployment D2. Skull and vertebrae of carcass are apparent in each image. (a) 29 small and 1 large Munidopsis crassa at carcass remains (M. crassa are not easily seen at image resolution); (b) $6 \mathrm{~h}$ later, M. crassa numbers have declined to 7, coincident with appearance of a Benthoctopus sp.; (c) $6 \mathrm{~h}$ later, M. crassa numbers have increased to 13. Note the 2 positions of the Benthoctopus sp. in the centre of the stretcher, and in the corner of the field of view; these were the only 2 positions observed throughout deployment. Scale bars $=10 \mathrm{~cm}$ 
reaching either their peak or their previous maximum, whichever came first) differed significantly (ANCOVA, $\mathrm{df}=4, F=211.8, \mathrm{p}<0.001)$, and were notably faster following Events 1 and $2(\mathrm{~m}=1.08$ and 0.82, respectively) than following Events 3, 4, and $5(\mathrm{~m}=0.28,0.29$, 0.34 , respectively; $\mathrm{m}=$ increase in number of $M$. crassa per image).

Ophiuroids and asteroids arrived within 15 d (always $\leq 2$ individuals frame ${ }^{-1}$ ). Individual holothurians passed through the field of view occasionally, but were not quantified. Small Peniagone sp., probably P. diaphana, were apparent in large numbers (max. 49 individuals) on Days 6 and 7. Single amphipods were occasionally discernible at the D2 carcass (5 visible over the first $10 \mathrm{~d})$. In a single image, 14 were visible aggregated on the tail of the carcass; this was the only observed aggregation and quantification throughout the deployments was not attempted. Most were approximately 15 to $25 \mathrm{~mm}$ in total length and were identified as Eurythenes gryllus.

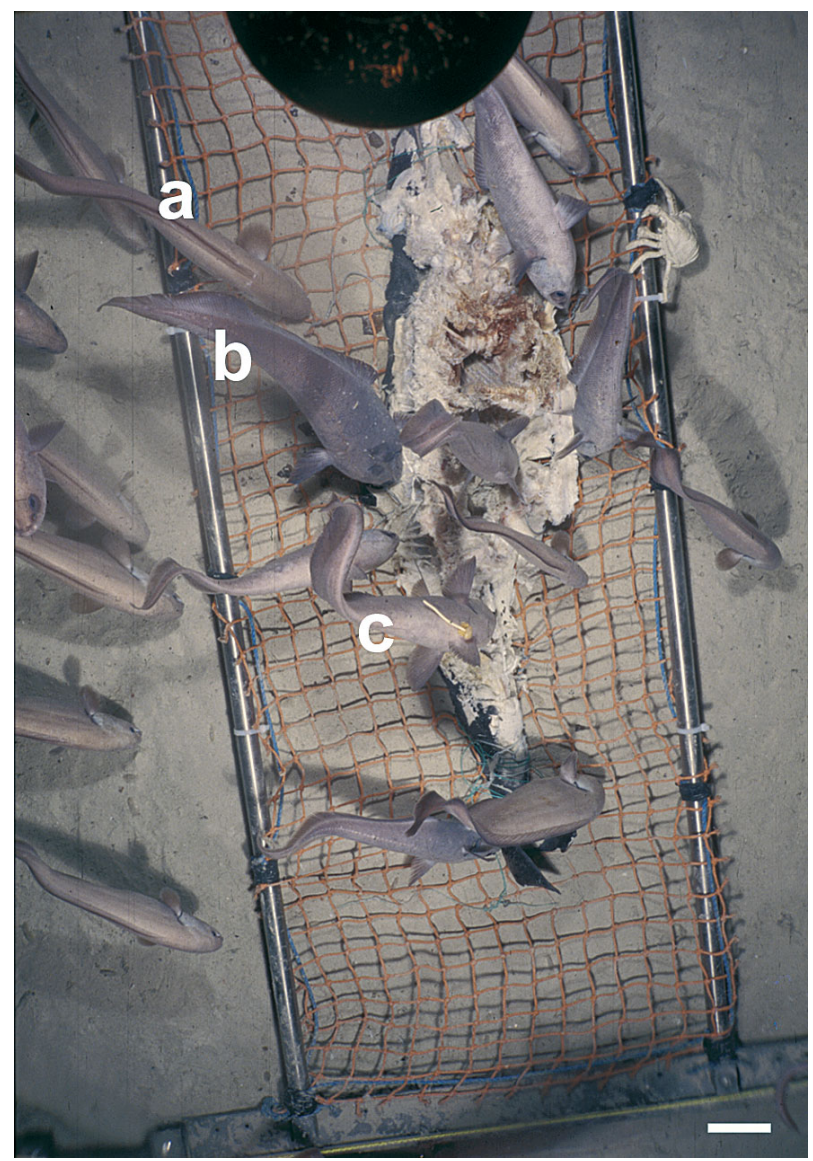

Fig. 4. Feeding postures at deployment D2. Spectrunculus grandis (a) were predominantly observed at periphery of image and near, but not directly on the carcass. Coryphaenoides armatus (b) were often in perpendicular orientation suggestive of direct feeding; One $C$. armatus (c) with a copepod ectoparasite was repeatedly identified at the carcass. Scale bar $=10 \mathrm{~cm}$

\section{Feeding behaviour}

Although Coryphaenoides armatus and Spectrunculus grandis were observed in comparable numbers at both D1 and D2, their behaviour at the sites differed notably. C. armatus were usually oriented over the carcass itself, often perpendicular to the seafloor, with their head at the carcass and their tails towards the camera. In contrast, $S$. grandis were consistently observed in the periphery of the field of view, not directly attending the carcass (Fig. 4).

Direct feeding activity was difficult to discern from the vertical view of the images, however Coryphaenoides armatus, Spectrunculus grandis and Antimora rostrata were all photographed at D1 with porpoise entrails in their mouths, confirming direct scavenging. Sharks were not photographed directly feeding, but large lesions consistent with the size of the imaged sharks and which occurred immediately following each shark visit in D1 suggest that sharks may have played a significant role in consumption of the D1 bait.

The recovered portion of the D1 carcass weighed $12.32 \mathrm{~kg}$, (consumption rate $0.085 \mathrm{~kg} \mathrm{~h}^{-1}$ ) and bite marks were visible on the remaining flesh (Fig. 5a,b) and on the wall of the stomach cavity. Clear teeth marks separated by $2.5 \mathrm{~mm}$ were visible around some of these bites. There were small holes around the head region suggestive of amphipod scavenging although amphipods were not apparent in the images (Fig. 5c). A single amphipod was found in the intercostal muscle.

The soft tissue of D2 had been completely removed by Day 15 (consumption rate $0.078 \mathrm{~kg} \mathrm{~h}^{-1}$ ), leaving only bones and a large section of skin. The skin was removed from the field of view in 2 large pieces on Days 22 and 56 (Fig. 6). The skull and many vertebrae remained visible in the last image; no bones were retrieved.

Consumption of both D1 and D2 carcasses began around the eye area of the animal, and around incision points in the bodies that existed prior to deployment.

\section{Length frequency}

D1 Coryphaenoides armatus were significantly larger $( \pm 95 \% \mathrm{CI}$, mean total length $=433 \pm 11 \mathrm{~mm}, \mathrm{n}=80)$ than those photographed at D2 $( \pm 95 \% \mathrm{CI}$, mean total length $=359 \pm 13 \mathrm{~mm}, \mathrm{n}=58$ ) (Students $t$-test, $\mathrm{p} \leq 0.001, t=8.3$ ). This difference remains significant when only the first week of D2 data is considered ( $t$-test, $\mathrm{p} \leq 0.001, t=5.84$ ), indicating that it does not solely reflect a decrease in the size of fish visitors over the longer deployment period of D2, or a seasonal change in population structure. Regression analyses of mean total lengths of $C$. armatus do not indicate a significant change over the deployment durations of D1 $(F=0.33, \mathrm{p}=0.57)$ or D2 $(F=0.56, \mathrm{p}=0.46)$. 
D1 Spectrunculus grandis were also significantly larger $( \pm 95 \% \mathrm{CI}$, mean total length $=460 \pm 16 \mathrm{~mm}, \mathrm{n}=$ $85)$, than at D2 $( \pm 95 \%$ CI, mean total length $=398 \pm$ $18 \mathrm{~mm}, \mathrm{n}=57$ ) (Student's $t$-test, $\mathrm{p} \leq 0.001, t=5.2$ ). Very large individuals (>900 mm) were observed periodically at both D1 and D2; these were not included in mean length calculations as their large size meant they were
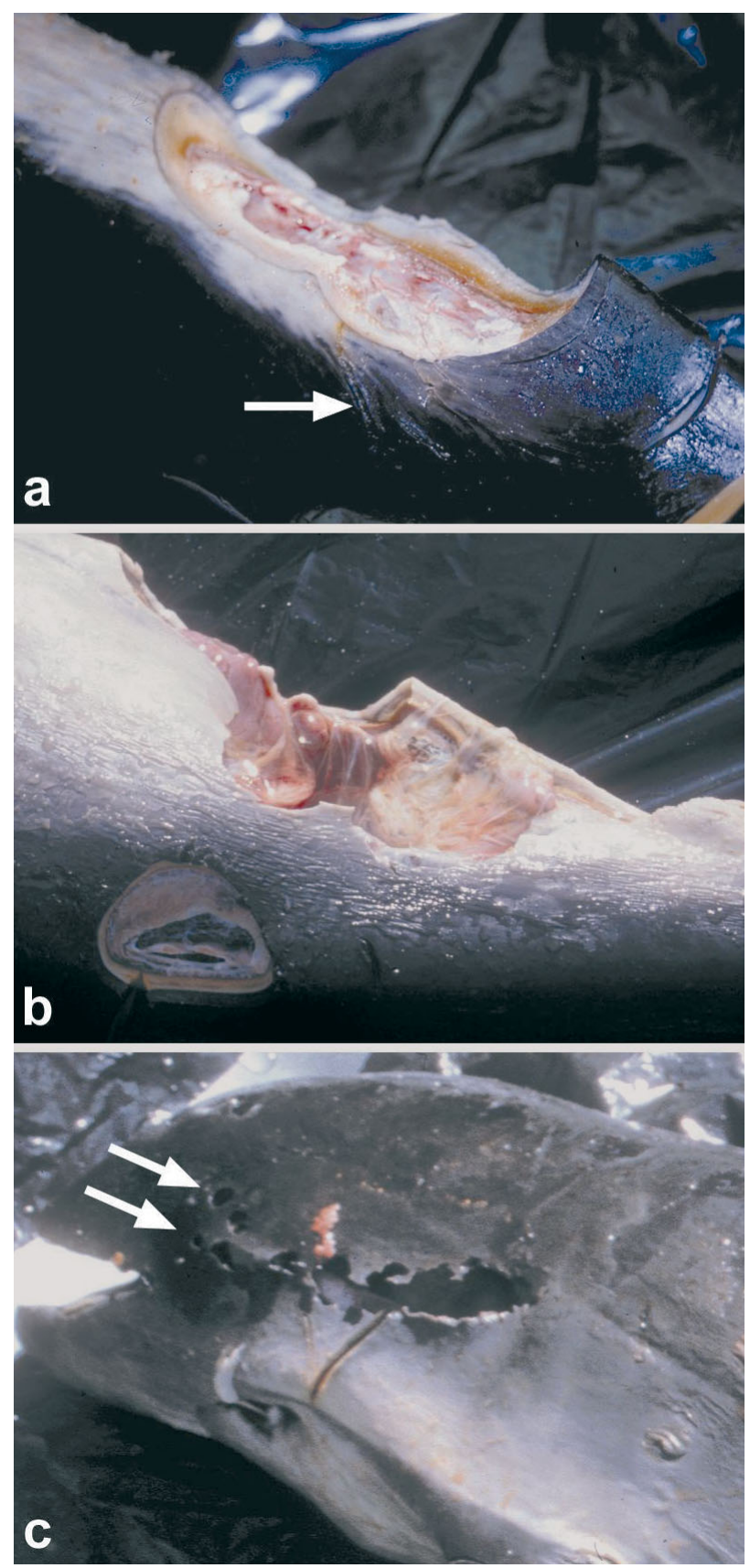

Fig. 5. Details of retrieved carcass of deployment D1. (a) Teeth marks visible on dorsal surface surrounding areas of removed flesh; (b) neat bites have been removed from ventral surface; (c) holes in the skin of the head that was in contact with the seafloor are suggestive of amphipod scavenging (arrows) never captured completely in the images. Although these larger, paler fish have been classified and described as male $S$. grandis (Nielsen \& Hureau 1980) recent work reviewing ophidiid taxonomy suggests they may in fact be a different species (P. Møller pers. comm.). Regression analyses of $S$. grandis mean total length does not indicate a significant change over the deployment duration of D2 $(F=1.4, \mathrm{p}=0.25)$, but does indicate a decrease in length during D1 $(F=6.4, \mathrm{p}=0.01)$.

\section{DISCUSSION}

The experimental design required that the carcasses be delivered to approximately the same depth in the Porcupine Seabight, however the topography of the region and drift of the DOBO during descent made this impossible. The difference in the depths (2555 and $2710 \mathrm{~m})$, and consequently temperatures $\left(2.8\right.$ and $\left.2.0^{\circ} \mathrm{C}\right)$ may have affected the composition of the scavenging community, but it is nevertheless useful to combine the data from the 2 experiments to provide insight into the succession of species that attend carcasses at bathyal depths.

\section{Consumption}

The main consumer of the soft tissue of both carcasses appears to have been Coryphaenoides armatus. Video observations from baited cameras deployed in the Porcupine Seabight confirm that C. armatus actively tear flesh from smaller bait parcels (Oceanlab, Aberdeen University unpubl.), and the orientation of individual fish perpendicular to the carcass is suggestive of this feeding behaviour. C. armatus numbers at D2 peaked early after deployment and steadily declined as the flesh of the carcass was removed. The rapid decline in $C$. armatus numbers coincided with the bulk of the soft tissue having been removed, further suggesting that this species utilised the carcass by direct scavenging.

Coinciding with the decrease in fish numbers was the steady increase in numbers of Munidopsis crassa at D2. Although the walking speed of small M. crassa is slow relative to swimming fishes, anomuran crabs have been observed to arrive very quickly at baits (Collins et al. 2002), and their late arrival in this instance may reflect predator avoidance behaviour to some extent (stomach contents of both Spectrunculus grandis and Coryphaenoides armatus include decapod crustaceans) (Mauchline \& Gordon 1984, Gordon \& Duncan 1987). The pattern of arrival also denotes niche separation and temporal succession amongst the highly mobile scavenging species. Removal of the bulk of the soft tissue by $C$. armatus, exposing bone and 


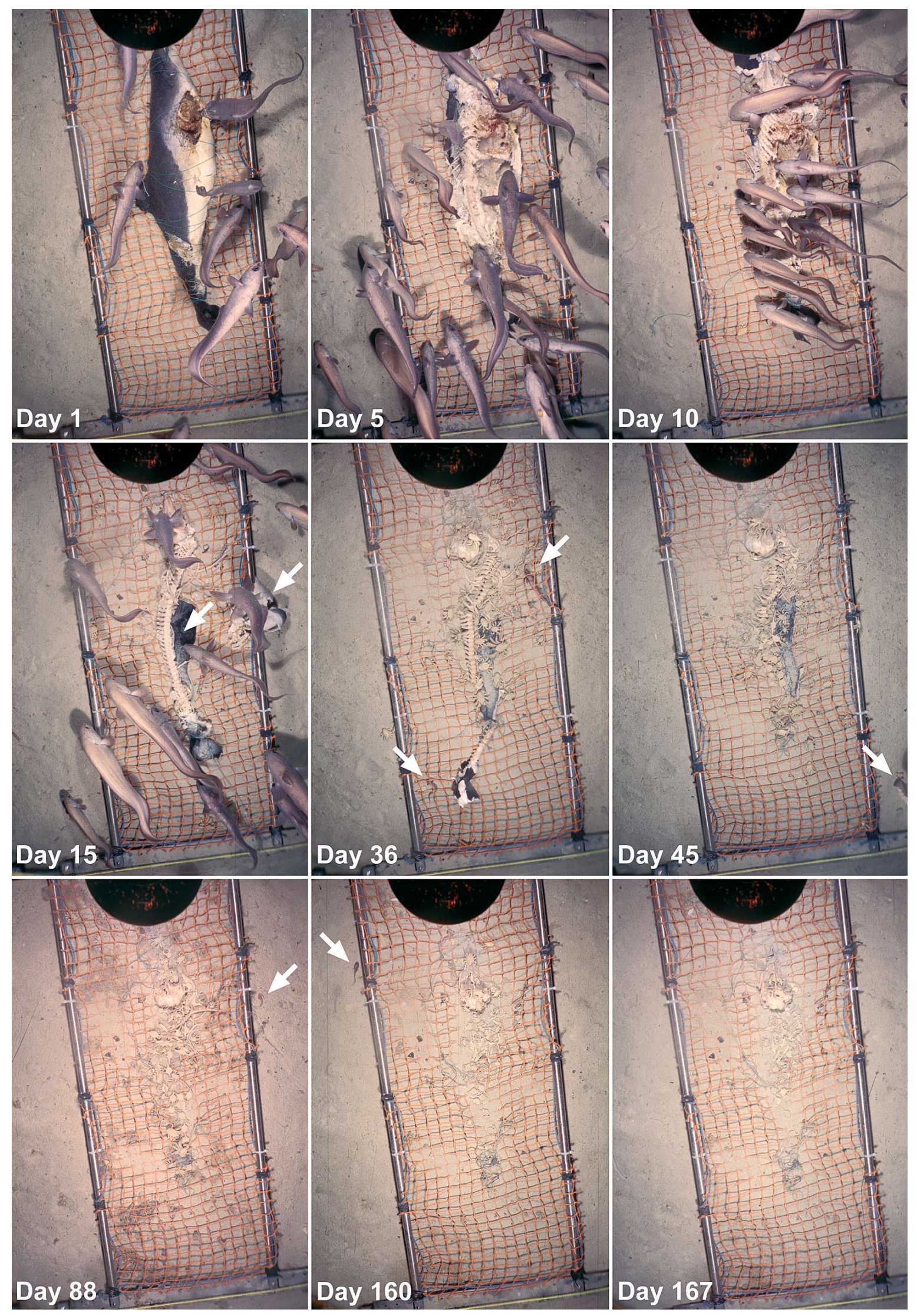


Fig. 6. Selected images spanning duration of deployment D2. Coryphaenoides armatus and Spectrunculus grandis dominated scavenging fauna in initial stages (Days 1,5,10). By Day 15 the soft tissue of the flesh had been completely removed except for 2 pieces of thick skin (arrows). Zoarcids (arrows) became a notable presence around Day 36. The tail had been removed in one piece on Day 45 (arrow). Munidopsis crassa dominated scavenging assemblage following the removal of the soft tissue. A hemichordate lophenteropneust appeared on Day 88, and a juvenile macrourid on Day 160 (see arrows). Last image of D2 was taken on Day 167; by this time remaining bones of the carcass and mesh net had become partially buried in sediment

small tissue remnants may have facilitated the scavenging activity of M. crassa.

The role of amphipods in the present study is uncertain. Because of their small size, their numbers have undoubtedly been underestimated. Temperature and pressure changes may have caused them to abandon the carcass during recovery and explain their near absence in the recovered carcass of D1. However, signs of amphipod predation on the recovered carcass were limited to some small holes around the head region, suggesting that amphipods did not contribute greatly to the initial stages of consumption at these slope depths. Amphipods may constitute $2.5 \%$ of the Porcupine seabight macrofauna (Gage et al. 1980), but the distribution of demersal lysianassid amphipods is thought to be patchy (Ingram \& Hessler 1983). The low numbers detected may reflect low local abundance.

\section{Species interactions}

The influence of the food falls on local community structure was not limited to the scavenging fauna. Spectrunculus grandis have been observed at shortterm baited cameras in the NE Atlantic (Armstrong et al. 1992, Jones et al. 1998, Collins et al. 1999, Henriques et al. 2002), always in low numbers $\left(\leq 3\right.$ frame $\left.^{-1}\right)$. In contrast, maxima of 8 and $15 \mathrm{~S}$. grandis frame ${ }^{-1}$ were observed at D1 and D2 respectively and this species dominated the vertebrate fauna in terms of total number observed and percentage of images in which they occurred (Table 1). S. grandis numbers at the D2 carcass peaked after the bulk of the soft tissue had been consumed. This arrival pattern, and their peripheral positioning at the carcass suggests that $S$. grandis were attracted as predators targeting the invertebrate scavenger assemblage, rather than direct consumers of the carcass. They may even have been responsible for the surprisingly low numbers of amphipods observed. Amphipods constitute the dominant prey item of $S$. grandis at slope depth in the nearby Rockall Trough, constituting $12.8 \%$ of total stomach contents (Gordon \& Duncan 1987). Smaller food falls (fishes) in the NE Atlantic are consumed rapidly by macrourids and blue hake, and may not persist sufficiently long for a scavenging invertebrate assemblage to become established. Although bait odour may act as the primary attractant for $S$. grandis, they may not remain at a bait if invertebrate prey items are low in abundance.

Zoarcids were not a notable presence at the carcass until Day 36 and did not appear to feed directly on the carcass, suggesting that they also were targeting the invertebrate assemblage, and may have been outcompeted initially by Spectrunculus grandis. The staying times of zoarcids (6 to $9 \mathrm{~h}$ on several occasions, although individual identifications could not be confirmed), were consistent with observations of roosting at other food fall sites (Jones et al. 1998, Witte 1999).

The octopus observed in D2 appears to have been 1 individual making recurrent visits to the carcass, and assessment of its behaviour has been based on this assumption, although the possibility that more than 1 individual was observed cannot be completely ruled out. This species also utilised the D2 food fall as a feeding site, eliciting a marked avoidance response in Munidopsis crassa. The octopus moved off the carcass site immediately following the first 3 attacks, and the rapid recovery of $M$. crassa numbers at this point suggests that it did not pose an immediate threat following a feeding event and that $M$. crassa were not moving far from the carcass during the octopus attacks. Preyhandling behaviour of deep-sea octopods has not been described, however crustaceans form an important component of the diet of shallow-water benthic octopods (Boyle \& Knobloch 1981, Nixon 1987). Octopods feeding on crustacean prey may bore through the hard carapace before injecting digestive enzymes into the flesh and extracting the digested tissue. Toxins in the saliva of the octopus paralyse the crustacean prey and proteolytic enzymes facilitate the detachment of muscle from the carapace (Key et al. 2001 and references therein). Whilst occupied with prey-handling and digestion, octopus may not represent an immediate danger to other prey organisms. The rapidity of recovery following Octopus Events 1 and 2 suggests a reappearance of individuals that had moved temporarily off the carcass during the octopus event, rather than the arrival of new individuals.

Between the third and fourth events the octopus changed its behaviour and remained within the vicinity of the carcass for $8 \mathrm{~d}$. The slower recovery rate and the notable reduction of Munidopsis crassa numbers following this change may reflect both the reduction in the food source and a predator-avoidance response elicited by the close proximity of the octopus. 
Antimora rostrata numbers were notably lower than expected. Baited camera studies in the Porcupine Seabight have observed $A$. rostrata to be the main consumer of fish baits at $2500 \mathrm{~m}$, arriving first and reaching a maximum of 6 individuals frame ${ }^{-1}$ (Collins et al. 1999). A. rostrata and Coryphaenoides armatus occupy a similar scavenging niche in overlapping depth zones (Collins et al. 1999), but D2 was close to the limit of the bathymetric distribution of A. rostrata, which may account for the low numbers observed. Compared with their high abundance at small food falls at similar depth (Collins et al. 1999), the numbers of $A$. rostrata were also low in D1. The tough skin and blubber layer of the largely complete D1 carcass may have reduced the odour signal from the carcass, and A. rostrata may simply have a preference for fish bait. A similar presence at fish baits and absence at cetacean baits has been noted for the sablefish Anoplopoma fimbria and the brittlestar Ophiophthalmus normani (Smith \& Baco 2003) at bathyal food falls in the Pacific. Many predatory teleosts are also facultative scavengers (Britton \& Morton 1994), but the importance of necrophagy as a feeding method seems to increase with increasing depth (Stockton \& DeLaca 1982). The shallower living, faster-swimming (Collins et al. 1999) Antimora rostrata may be more selective in its scavenging habits, perhaps preferring bait more similar to its natural prey.

None of the vertebrate species observed at the D1 and D2 food falls are obligate necrophages. Britton \& Morton (1994) suggested that any species which relies exclusively on scavenging (in an environment where carrion may be rare) must be at a selective disadvantage. However species capable of locating and supplementing their diet with an occasional carrion windfall are at a distinct competitive advantage. Coryphaenoides armatus typifies this premise.

\section{Fish foraging behaviour and time spent at carcass}

Coryphaenoides armatus were present at the D2 carcass for the first $45 \mathrm{~d}$ of observation. The question arises as to whether the same individuals were present throughout this time or whether there was a continuous turnover of fish that arrived, fed and then departed. The mean staying time of $C$. armatus at abyssal food falls has been estimated at 27 min (max. $2 \mathrm{~h} 50 \mathrm{~min}$ ) from image analysis (Jones et al. 1998) and at 1.5 to $8 \mathrm{~h}$ from analysis of $C$. armatus tagged with ingestible acoustic transponders (staying time in this instance defined as within $150 \mathrm{~m}$ of the carcass) (Jones 1999). In the present study, 1 individual $C$. armatus with a large copepod ectoparasite could be readily identified, and appeared $6 \mathrm{~d}$ after touchdown during
D2. It stayed for 3 successive images (9 h), was absent from the following image, and then reappeared for 3 more successive frames. It was not identified again for the duration of the 7 mo experiment (although the ectoparasite used for identification could have been removed). The visiting behaviour of this fish suggests a much longer staying time at the D2 carcass of 18 to $21 \mathrm{~h}$.

If the parasite-bearing Coryphaenoides armatus is regarded as representative of the staying time and visiting pattern of this species at D2, then the arrival rate of $C$. armatus may be estimated as:

$$
n / t_{\mathrm{s}}=A_{\mathrm{r}}
$$

where $n=$ number of fish present (daily mean at D2 = $6.4), t_{\mathrm{s}}=$ staying time $(18 \mathrm{~h})$, and $A_{\mathrm{r}}=$ arrival rate. Consequently, the total number attracted to the carcass may be estimated as:

$$
A_{\mathrm{r}} \times t=n_{t}
$$

where $t=$ total time $(15 \mathrm{~d})$ and $n_{t}=$ total number of fish present over time $t$.

Based on this assumption, 129 C. armatus visited the D2 food fall in the first $15 \mathrm{~d}$, during which time the soft tissue was completely removed. Discounting scavenging by amphipods, and assuming that direct feeding by Spectrunculus grandis was minimal, this would mean that each C. armatus consumed $0.2 \mathrm{~kg}$ of flesh $(28 \mathrm{~kg}$ D2 carcass/129 fish). Substituting $18 \mathrm{~h}$ for the previously published estimate of $C$. armatus, the staying time of $27 \mathrm{~min}$ (Jones et al. 1998) yields an estimated total number (at the D2 carcass) of 5112 fish, and a consumption per fish of $0.005 \mathrm{~kg}$.

Neither of these estimates should be regarded as 'representative' of Coryphaenoides armatus behaviour at a food fall. Staying time at a food patch may be variably determined by levels of satiation, expectation of alternative food sources (marginal value theorem) and the level of risk associated with staying at the food patch. These conditions will vary between food fall sites. For example, large scavenging amphipods such as Eurythenes gryllus are capable of attacking and devouring constrained live fishes (Templeman 1967) and may pose some risk to feeding fishes; these amphipods have been reported to be prevalent at abyssal food falls (Jones et al. 1998). However their absence from the D2 food fall may have enabled fishes to linger at the carcass, possibly feeding to satiation before departing. Comparisons between conditions at each location are therefore more informative than a generalised model of $C$. armatus feeding behaviour. Furthermore estimates of fish numbers and individual consumption enable an approximation of the lateral distribution of carbon from the food fall. This distribution is directly dependent on the dispersal of departing scavengers, primarily C. armatus. 
The potential impact of a large food fall on the local fauna depends on its depth, its size, the background species assemblage, and the availability of alternative food. Direct consumption of bathyal whale falls in the Pacific was initially by hagfish and sharks (absent at abyssal depth); amphipods arrived later, within 0.5 to 1.5 mo (Smith et al. 2002). This pattern is comparable to the direct scavenging by fishes and the reduced amphipod presence observed at D1 and D2, and contrasts markedly with observations in the abyssal Atlantic (Jones et al. 1998). The observation that large whale falls pass through at least 3 successional stages (mobile scavenging, enrichment opportunist, and sulphophilic) (Smith \& Baco 2003) does not necessarily extend to smaller macrocarrion. Certainly, Smith \& Baco (2003) observe that 'a minimum size/degree of calcification [is] required [to ensure the slow decomposition and release of bone-lipid reserves which] sustain chemoautotrophic communities' (the sulphophilic stage). Porpoise and dolphin carcasses, and even juveniles of some larger cetacean species, fall below this threshold. Furthermore the bone of large whales may comprise $60 \%$ lipid (Allison et al. 1991), greatly exceeding estimates of $10 \%$ for smaller cetaceans (Honda et al. 1984). Although the organic breakdown of the bone of smaller carcasses may ultimately result in some enrichment and eventual reduction of the sediment environment, there is little evidence to support the establishment of an enrichment opportunist stage at macrocarrion food falls in the Atlantic, even over a 6 mo observation period.

The order of magnitude difference in consumption rates observed between bathyal whale falls in the Pacific (1.67 and $2.50 \mathrm{~kg} \mathrm{~h}^{-1}$ ) (Smith et al. 2002) and bathyal and abyssal cetacean falls in the Atlantic $(0.05$ to $0.085 \mathrm{~kg} \mathrm{~h}^{-1}$ ) (Jones et al. 1998) indicates a fundamental difference in the scavenger response in the 2 areas. Furthermore consumption rates of small and large food falls in the Pacific can be described by a single logarithmic curve that does not fit the abyssal Atlantic data. These observations led Smith \& Baco (2003) to speculate that the mobile scavenger stage for large whale falls may last longer in the abyssal Atlantic. This is indirectly supported by our observations at D1 and D2 which, despite their much shallower placement, were consumed at rates comparable to those in the Atlantic abyss and were an order of magnitude slower than rates at bathyal food falls in the Pacific. However, care should be taken in extending these observations to whole oceans. The majority of food fall observations in the North Pacific have been off the Californian coast, under the migration path of the grey whale Eschrichtius robustus and near the feeding grounds of humpback and blue whales (among others). Benthic and benthopelagic scavengers in this region may thus benefit from a far greater frequency of naturally occurring food falls. Smith and Baco (2003) speculated that pulses of organic carbon to bathyal depths in this region may be common enough to have allowed the evolution of bathyal enrichment opportunists, and this successional stage was apparent even at small food parcels (Smith 1985). Although these conditions do not apply to the Porcupine region of the North Atlantic, the faunal response under major Atlantic migration routes may compare more closely.

It is clear that the impact of the porpoise carcasses deployed in the Porcupine Seabight extended beyond that of a food source utilised by mobile scavengers. They became points of interaction between scavenging and non-scavenging species existing in a relatively featureless environment. Observation beyond the initial early scavenging stage was made possible for the first time in the North Atlantic through the use of a longterm lander platform. High frequency monitoring revealed rapid episodic changes in species presence (as exemplified by the octopus events) that would very likely be overlooked in studies using occasional visits by manned or unmanned diving systems, and increased the likelihood of observing rare visitors such as the seldom photographed enteropneusts (Lemche et al. 1976, Thorndike et al. 1982) and juvenile macrourids.

Acknowledgements. This work was supported by NERC grants GR3/12789 and JIF H/S/1999/00163. We thank the ships, company and crews of RRS 'Discovery' cruises 255 and 260. Many thanks to R. Reid at The Scottish Agricultural College Wildlife Unit, Inverness, for supplying the carcasses, and to N. Merrett, M. Thurston and K. Howell for assistance with species identifications. Thanks also to M. Solan for assistance with early drafts.

\section{LITERATURE CITED}

Allison PA, Smith CR, Kukert H, Deming JW, Bennett BA (1991) Deep-water taphonomy of vertebrate carcasses: a whale skeleton in the bathyal Santa Catalina Basin. Paleobiology 17:78-89

Armstrong JD, Bagley PM, Priede IG (1992) Photographic and acoustic tracking observations of the behaviour of the grenadier, Coryphaenoides (Nematonurus) armatus, the eel Synaphobranchus bathybius, and other abyssal demersal fish in the North Atlantic Ocean. Mar Biol 112: 535-544

Bennet BA, Smith CR, Glaser B, Maybaum HL (1994) Faunal community structure of a chemoautotrophic assemblage on whale bones in the deep northeast Pacific ocean. Mar Ecol Prog Ser 108:205-223

Boyle PR, Knobloch D (1981) Hole boring of crustacean prey by the octopus Eledone cirrhosa (Mollusca: Cephalopoda). J Zool 193:1-10

Britton JC, Morton B (1994) Marine carrion and scavengers. Oceanogr Mar Biol Annu Rev 32:369-434

Collins MA, Priede IG, Bagley PM (1999) In situ comparison of activity of two deep-sea scavenging fish occupying 
different depth zones. Proc R Soc Lond B 266:2011-2016

Fowler SW, Knauer GA (1986) Role of particles in the transport of elements and organic compounds through the oceanic water column. Prog Oceanogr 16:147-194

Gage JD (1990) Skeletal growth markers in the deep-sea brittlestars Ophiura ljungmani and Ophiosium lymani. Mar Biol 104:427-435

Gage JD, Tyler PA (1985) Growth and recruitment of the deep-sea urchin Echinus affinis. Mar Biol 90:41-53

Gage JD, Lightfoot RH, Pearson M, Tyler PA (1980) An introduction to a sample time-series of abyssal macrobenthos: methods and principle sources of variability. Oceanol Acta 3:169-176

Gordon JDM, Duncan JAR (1987) Deep-sea bottom-living fishes at two repeat stations at 2200 and $2900 \mathrm{~m}$ in the Rockall Trough, northeastern Atlantic Ocean. Mar Biol 96: 309-325

Henriques C, Priede IG, Bagley PM (2002) Baited camera observations of deep-sea demersal fishes of the Northeast Atlantic Ocean at $15^{\circ}-28^{\circ} \mathrm{N}$ off West Africa. Mar Biol 141: 307-314

Honda K, Fujise Y, Tatsukawa R, Miyazaki N (1984) Composition of chemical components in bone of striped dolphin, Stenella coeruleoalba: distribution characteristics of major inorganic and organic components in various bones, and their age-related changes. Agric Biol Chem 48:409-418

Ingram CL, Hessler RR (1983) Distribution and behaviour of scavenging amphipods from the central North Pacific. Deep-Sea Res 30:683-706

Jamieson AJ, Bagley PM (2005) Biodiversity survey techniques: ROBIO and DOBO landers. Sea Technol Jan:52-54

Janßen F, Treude T, Witte U (2000) Scavenger assemblages under differing trophic conditions: a case study in the deep Arabian Sea. Deep-Sea Res II 47:2999-3026

Jones EG (1999) 'Burial at sea'; consumption and dispersal of large fish and cetacean food-falls by deep-sea scavengers in the northeast Atlantic ocean and eastern Mediterranean sea. $\mathrm{PhD}$ thesis, University of Aberdeen

Jones EG, Collins MA, Bagley PM, Addison S, Priede IG (1998) The fate of cetacean carcasses in the deep sea: observations on consumption rates and succession of scavenging species in the abyssal north-east Atlantic Ocean. Proc R Soc Lond B 265:1119-1127

Key LN, Boyle PR, Jaspars M (2001) Novel activities of saliva from the octopus Eledone cirrhosa (Mollusca; Cephalapoda). Toxicon 40:677-683

Lemche H, Hansen B, Madse FJ, Tendal OS, Wolff T (1976) Hadal life as analysed from photographs. Vidensk Medd Dan Naturhist Foren 139:263-336

Mauchline J, Gordon JDM (1984) Diets and bathymetric distributions of the macrourid fish of the Rockall Trough, northeastern Atlantic Ocean. Mar Biol 81:107-121

Editorial responsibility: Howard I. Browman (Associate Editor-in-Chief), Storebø, Norway
Nielsen JG, Hureau JC (1980) Revision of the ophidiid genus Spectrunculus Jordan \& Thompson, 1914, a senior synonym of Parabassogigas Nybelin, 1957 (Pisces, Ophidiiformes). Steenstrupia 6:149-169

Nixon M (1987) Cephalopod diets. In: Boyle PR (ed) Cephalopod life cycles, Vol 2. Academic Press, London, p 201-219

Priede IG, Bagley PM (1994) Seasonal change in activity of abyssal demersal scavenging grenadiers Coryphaenoides (Nematonurus) armatus in the eastern North Pacific Ocean. Limnol Oceanogr 39:279-285

Priede IG, Bagley PM (2000) In situ studies on deep-sea demersal fishes using autonomous unmanned lander platforms. Oceanogr Mar Biol Annu Rev 38:357-392

Priede IG, Merrett NR (1996) Estimation of abundance of abyssal demersal fishes; a comparison of data from trawls and baited cameras. J Fish Biol 49:207-216

Rice AL, Billett DSM, Thurston MH, Lampitt RS (1991) The Institute of Oceanographic Sciences biology programme in the Porcupine Seabight: background and general introduction. J Mar Biol Assoc UK 71:281-310

Rowe GT (1981) The deep sea ecosystem. In: Longhurst AR (ed) Analysis of marine ecosystems. Academic Press, London, p 235-267

Smith CR (1985) Food for the deep sea: utilization, dispersal, and flux of nekton falls at the Santa Catalina Basin floor. Deep-Sea Res 32:417-441

Smith CR, Baco AR (2003) Ecology of whale falls at the deep-sea floor. Oceanogr Mar Biol Annu Rev 41:311-354

Smith CR, Kukert H, Wheatcroft RA, Jumars PA, Deming JW (1989) Vent fauna on whale remains. Nature 341:27-28

Smith CR, Baco AR, Glover A (2002) Faunal succession on replicate deep-sea whale falls: time scales and vent-seep affinities. Cah Biol Mar 43:293-297

Stockton WL, DeLaca TE (1982) Food falls in the deep sea: ocurrence, quality, and significance. Deep-Sea Res 29: 157-169

Templeman W (1967) Predation on living fishes on longline in Baffin Bay by the amphipod Eurythenes gryllus (Lichtenstein), and a new distribution record. J Fish Res Board Can 24:215-217

Thorndike EM, Gerard RD, Sullivan LG, Paul AZ (1982) Longterm, time lapse photography of the deep ocean floor. In: Scrutton RA, Talwani M (eds) The ocean floor. John Wiley, New York, p 255-275

Tyler PA, Grant A, Pain SL, Gage JD (1982) Is annual reproduction in deep-sea echinoderms a response to variability in their environment? Nature 300:747-750

Witte U (1996) Seasonal reproduction in deep-sea spongestriggered by vertical particle flux? Mar Biol 124:571-581

Witte U (1999) Consumption of large carcasses by scavenger assemblages in the deep Arabian Sea: observations by baited camera. Mar Ecol Prog Ser 183:139-147

Submitted: April 21, 2005; Accepted: August 23, 2005

Proofs received from author(s): February 28, 2006 